\title{
Modeling compressor blades gas turbine in a marine environment to determine of the stress and possible damages
}

\section{Modelado de álabes de compresor de una turbinas de gas en un ambiente marino para determinar el esfuerzo y posibles daños}

\author{
VILLAGRÁN-VILLEGAS, Luz Yazmín†ं*1,2, PATIÑO-ORTIZ, Miguel ${ }^{1}$, HERNÁNDEZ-GÓMEZ, \\ Luis Héctor ${ }^{1}$ and PATIÑO-ORTIZ, Julián ${ }^{1}$
}

\begin{abstract}
${ }^{1}$ Instituto Politécnico Nacional, Escuela Superior de Ingeniería Mecánica y Eléctrica, Sección de Estudios de Posgrado e Investigación, Unidad Profesional Adolfo López Mateos "Zacatenco”, Edificio 5 3er. Piso, Col. Lindavista, C.P. 07300, Ciudad de México.

${ }^{2}$ Universidad Veracruzana, Facultad de Ingeniería Mecánica Eléctrica, Av. Venustiano Carranza S/N, Revolución, C. P. 93390, Poza Rica; Veracruz, México.
\end{abstract}

ID $1^{\text {st }}$ Autor: Luz Yazmín, Villagrán-Villegas / ORC ID: 0000-0003-3860-2923, CVU CONACYT ID: 96365

ID $1^{\text {st }}$ Co-author: Miguel, Patiño-Ortiz / ORC ID: 0000-0002-5630-8077, CVU CONACYT ID: 167388

ID $2^{\text {nd }}$ Co-author: Luis Héctor, Hernández-Gómez / ORC ID: 0000-0003-2573-9672, CVU CONACYT ID: 5107

ID $3^{\text {rd }}$ Co-author: Julián, Patiño-Ortiz / ORC ID: 0000-0001-8106-9293, CVU CONACYT ID: 219581

DOI: $10.35429 /$ JOIE.2021.17.5.20.24

Received April 16, 2021; Accepted June 30, 2021

\begin{abstract}
In this paper, the static simulation carried out on the blades of the seventh stage of the compressor of a gas turbine installed in an offshore oil platform is reported, the objective of this simulation is to have a means of analysis that confirms and complements the tests visual inspection (boroscopy), as well as non-destructive tests. In specific case of this compressor, the results of boroscopy were available, as well as the scanning electron microscope (SEM), with which it was possible to measure the roughness and evaluate the degradation of the blade surfaces after 30,000 hours of service operating in Cantarell, Mexico, in a very aggressive marine environment conditions, where the entry of solid particles is highly possible. The model of seventh stage's blade was obtained with a cloud of points. A finite element analysis was carried out with ANSYS software. Results showed wear modes were originated by a severe stinging action. Also, large craters, similar to those observed in solid particle erosion, were developed by at normal impact. The points, where peak stresses were calculated, correspond to those places in which corrosion and some irregular scratches similar to plowing action, was observed. These are the points in which failures take place. Results showed wear modes were originated by a severe stinging action.
\end{abstract}

Blades, Gas turbine, Optical 3DScanner, Finite element

\begin{abstract}
Resumen
En este trabajo se reporta la simulación estática realizada en los álabes de la séptima etapa del compresor de una turbina de gas instalada en una plataforma petrolera costa afuera, el objetivo de esta simulación es contar con un medio de análisis que confirme y complemente las pruebas de inspección visual (boroscopia), así como pruebas no destructivas. En el caso específico de este compresor, se empleraron los resultados de boroscopia, así como del microscopio electrónico de barrido (SEM), con el que se pudo medir la rugosidad y evaluar la degradación de las superficies de los álabes tras 30.000 horas de servicio operando en Cantarell, México, en un entorno marino muy agresivo, donde la entrada de partículas sólidas esta presente. El modelo de la álabe de la séptima etapa se obtuvo con una nube de puntos. Se realizó un análisis de elemento finitos con el software ANSYS. Los resultados mostraron que los modos de desgaste se originaron por una acción severa. Además, se desarrollaron grandes cráteres, similares a los observados en la erosión de partículas sólidas, con un impacto normal. Los puntos, donde se calcularon los esfuerzos máximos, corresponden a aquellos lugares en los que se observó corrosión y algunos rayones irregulares similares a la acción del arado. Los puntos analizados, son los puntos en los que se producen las fallas severas.
\end{abstract}

Alabes, Turbina de gas, Escanner 3D, Análisis de elemento finito

Citation: VILLAGRÁN-VILLEGAS, Luz Yazmín, PATIÑO-ORTIZ, Miguel, HERNÁNDEZ-GÓMEZ, Luis Héctor and PATIÑO-ORTIZ, Julián. Modeling compressor blades gas turbine in a marine environment to determine of the stress and possible damages. Journal of Innovative Engineering. 2021. 5-17: 20-24

*Correspondence to Author (e-mail: yvillagran@uv.mx)

$\dagger$ Researcher contributing as first Author. 


\section{Introduction}

Gas turbines operating in offshore oil installations are subject to the presence of solid pollutants, as well as the corrosive effect of sea salts, as is the case with this turbine, Solar Centaur 40 gas turbine, for this reason, special care must be taken in routine maintenance inspections in order to detect faults such as opening of blade clearances and leading and trailing edge erosion (caused by solid and liquid impacts on blades), airfoil (blade) fouling and pitting (caused by corrosion and surface deposits);

The Centaur 40 gas turbine has 11 stages in axial type air compressor, pressure ratio is 10.3: 1 and air flow inlet is $18.7 \mathrm{~kg} / \mathrm{sec}$ (41.3 lb / sec). Variable blades begin to open when the Pcd (Pressure compressor discharge) reaches approximately $32 \mathrm{psi}$ (gp) and fully open when Pcd reaches approximately $76.5 \mathrm{lb} / \mathrm{in} 2$ (gauge) [1].

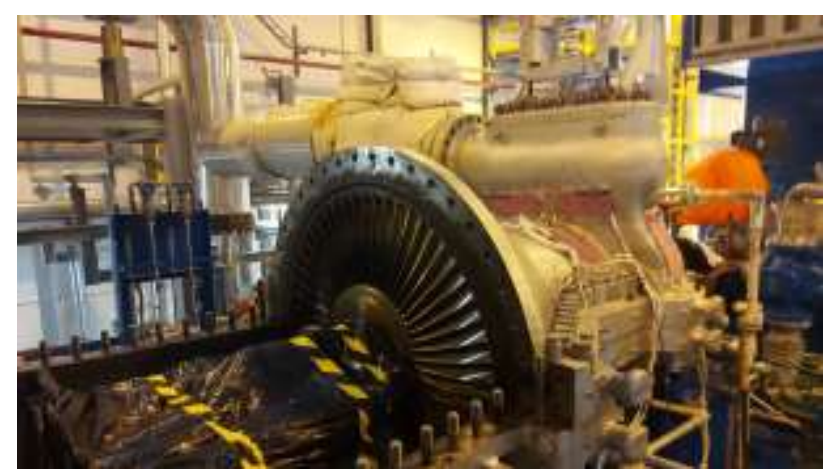

Figure 1 Blade rotor of compressor gas turbine Note. Adapted of Compressor turbine disk, VillagránVillegas Luz Yazmin, 2017

A study of wear damage of a seventhstage's blade of axial compressor of a gas turbine (see Figure 1) was carried out. Manufacturer recommends routine maintenance at 30,000 hours to reduce chances for shutdown of gas turbine, but the $\mathrm{C} 40$ gas turbine shutdown at 24,000 hours in field and out of service after 30,000 hours. In this study an analysis was made to model through computational dynamics the efforts to which it will be subjected and anticipate the operation shutdown time. [2].

As part of the inspection process carried out on the compressor, boroscopy studies and digital images were carried out, as well as scanning it with an electronic scanner. In order to carry out the dynamic simulation, the results of these inspections were used.

\section{Methodology: Scanning electron microscopy analysis}

The methodology developed where in the Emission Scanning Electron Microscopy analysis to carry out an analysis of damage caused by wear of blades of axial compressor on a gas turbine had three steps, the first chemical elements characterization, second, an inspection of both sides, trailing edge and leading edge of the blade and finally a microstructural test.

In the first step, it was obtained that blades are manufactured from a chrome-based superalloy with chemical elements such as Co, $\mathrm{Cr}, \mathrm{Ni}, \mathrm{Fe}, \mathrm{C}, \mathrm{Nb}$ and $\mathrm{Mo}$, this analysis was necessary to define in the software.

At the second step could, the analysis showed the degradation of surfaces in areas of higher air pressure mixed with particles, that it is hoped it can be confirmed in the modelling. In this phase of scanning, two techniques to preparation of the sample were used, first one analysis in trailing edge and then leading edge of the piece (Figure 2).

In microstructural tests, wear mechanisms characterized by large craters and grooves were identified, and degradation mechanisms were presented such as corrosion damage, irregular cavities, wear debris, flattened foreign particles on surface and parallel grooves showing the trajectory of solid particle impacted on the blade during its operation. [3]

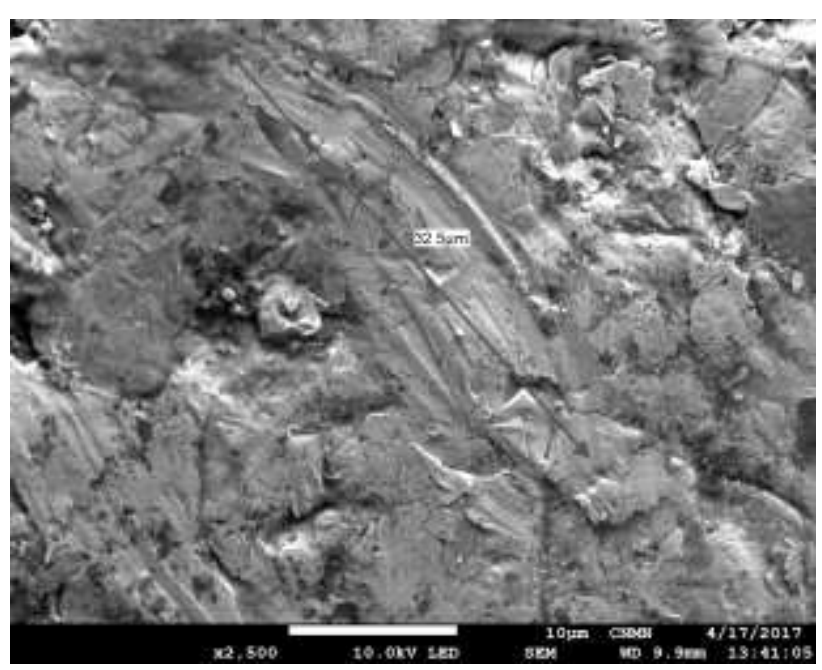

Figure 2 Irregular indentation and material piled-up (trailing edge)

Note. Adapted of Compressor turbine disk, VillagránVillegas Luz Yazmin, 2017 


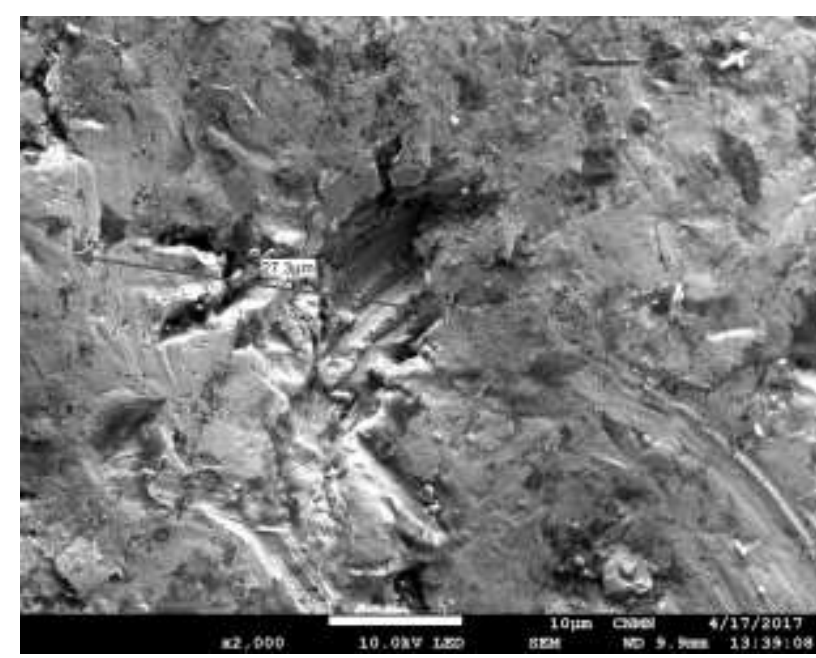

Figure 3 Trailing edge (Emission Scanning Electron Microscopy test)

Note. Adapted of Compressor turbine disk, VillagránVillegas Luz Yazmin, 2017

Figure 3 in trailing edge, present irregular indentations were identified on surfaces around $27.3 \mu \mathrm{m}$ length with material piled-up (lips) at sides as the result of subsequent particle impacts, which caused detachment of lips with trajectory around $32.5 \mu \mathrm{m}$.

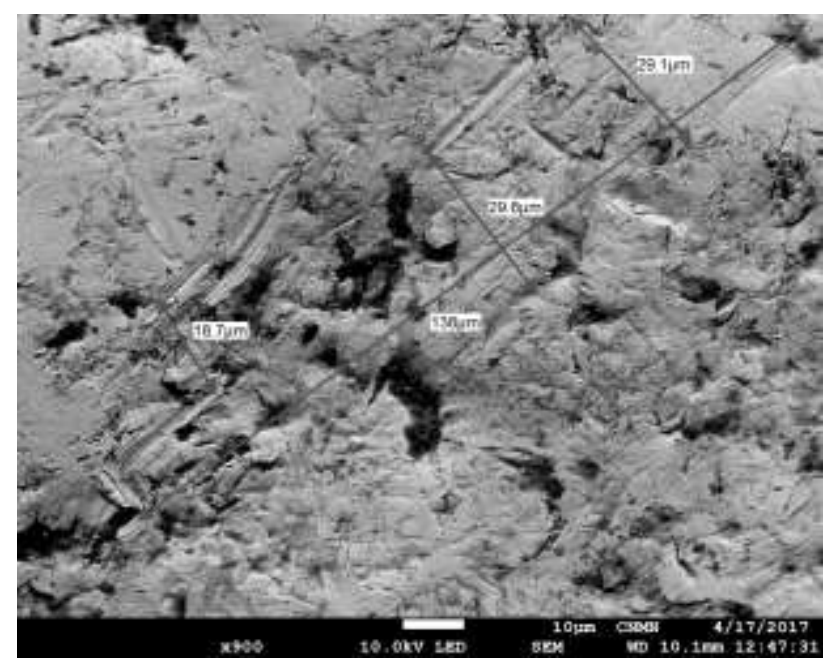

Figure 4 Leading edge (Emission Scanning Electron Microscopy test)

Note. Adapted of Compressor turbine disk, VillagránVillegas Luz Yazmin, 2017

Images in Figure 4 in leading edge, which are characterized by large craters and grooves (ploughing action) of around 0-138 $\mu \mathrm{m}$ length with material piled-up (lips) at sides around 4.7-15.2 $\mu \mathrm{m}$ length and in front of cavities, which is common in solid particle erosion, as specimens are impacted at oblique incident angles $\left(\alpha \leq 45^{\circ}\right)$

\section{Results: Numerical analysis}

Blades operate at great vibratory forces, which requires sufficient resistance to fatigue; in particular, they must be manufactured with careful processes to support wear and resonance conditions, [4] as well as to function optimally depending on pressure, temperature and viscosity conditions of fluid.

Another question that must be considered in the maintenance inspections is the variation in the geometry of the blade, [5] either due to wear or incrustations, since it would change the natural frequency of the set, bringing it closer to the designed natural vibration frequency, with the possible damage that this would cause. [6]

ATOS ScanBox is 3D optical measuring equipment that was developed by GOM This a software package for digital image correlation (DIC) and 3D motion analysis in materials and component testing. The software is used for the determination of material properties as well as for the validation and optimization of numerical simulations. GOM Correlate is applied in basic research, product development and failure analyses; It is an optical 3D coordinate measurement system. ATOS sensors provide full field 3D coordinates for each individual measurement of up to 16 million independent measurement points and are captured from 1 to 2 seconds. ATOS captures the full-surface geometry of an object accurately in a dense dot cloud or polygon mesh; it allows detailed high resolution scans, fast data collection, advanced inspection functionality and a complete dimensional analysis.

GOM Inspect is software for analysis of 3D measurement data. Generated model is a polygonal mesh that can be smoothed, thinned and refined, and from the initial model holes in the mesh can be filled and curvatures can be extracted. Mesh is processed using algorithms based on curvature and tolerances. Software provides the user with a preview of each processing step and generates calculation of an average mesh [7]; and solving meshing by approximations under the SST model SST Turbulence model, because of the limitations of the eddy viscosity modelling, flow models have been developed to better suit the turbulent flows found in turbo compressors. 
One of those are the Shear Stress Transport, that shows the distortional energy failure theory which is usually called the Von Mises stress, or effective stress model that from now on will be addressed as the SST model. The SST is based on the $\mathrm{K}-\omega$ model and is the standard turbulence used for simulations on centrifugal compressors because of its ability to predict the flow separation under unfavourable pressure gradient that are found in compressors. The model takes into account for the transport of the turbulent shear stress and take advantage of both the Wilcox and $\mathrm{K}$ - model. It solves both transport equation for kinetic energy as well as specific dissipation rate. This makes the SST model more sophisticated and accurate than its predecessors and is suitable for a larger range of different flows, like compressors and aerodynamics. The SST model is identical to the $\mathrm{K}-$ model in the free shear flows. At near walls, the prediction of separation from a smooth surface with high accuracy is difficult, especially under unfavourable pressure gradients like in the compressor.

It is recommended in the user guide to properly resolve the boundary layer with at least 10 layers (in this case, the software solved 18 positions) for the SST model to capture the flow correctly and with high accuracy at boundaries. This is especially of importance when solving for heat transfer [8]. Throughout this study, the SST model is used for simulations together with an automatic wall function.

This automatic wall function will switch from wall function to a low-Re near wall treatment when the mesh is refined. As already mentioned, SST is recommended for accurate predictions near wall, but is mathematically identical to the $\mathrm{K}$ - model in the free stream. By using the automatic near-wall treatment, the SST model will shift from a low-Re number form to a wall function formulation when the mesh is refined. This shift will be carried out to smoothly shift between the two formulations, so the lowRe formulation is used for $\mathrm{y}+<2$.

Therefore at least 10 layers of inflation should be used, so the wall can be resolved enough. Since the condition of $y+\leq 2$ is difficult to adapt in all parts of the geometry, the SST model with automatic near-wall treatment will shift between low-Re and wall function for $\mathrm{y}+<$ 11.06 .
By resolving the mesh by the use of inflation layer, so the mesh is below these criteria, the simulation does not have to switch between different wall functions, which may lead to an increased accuracy for the solver. Calibration process of equipment starts with selection of the type of calibration to be carried out, which depends on precision and number of calibration positions, for this case a calibration of 18 positions is chosen. At the start of calibration process, ambient temperature measurement was $21.4^{\circ} \mathrm{C}$ and ambient temperature recorded for blade scan was $27.1^{\circ}$ C.

Piece evaluated with blue light of ATOS scanner is a compressor vane of 7 th stage, which when mounted on turntable, a point cloud is obtained. Data acquisition procedure (Figure 5) requires that the piece is coated with a white paint film (zinc oxide), for this testing stage the piece was already evaluated in RX and SEM.

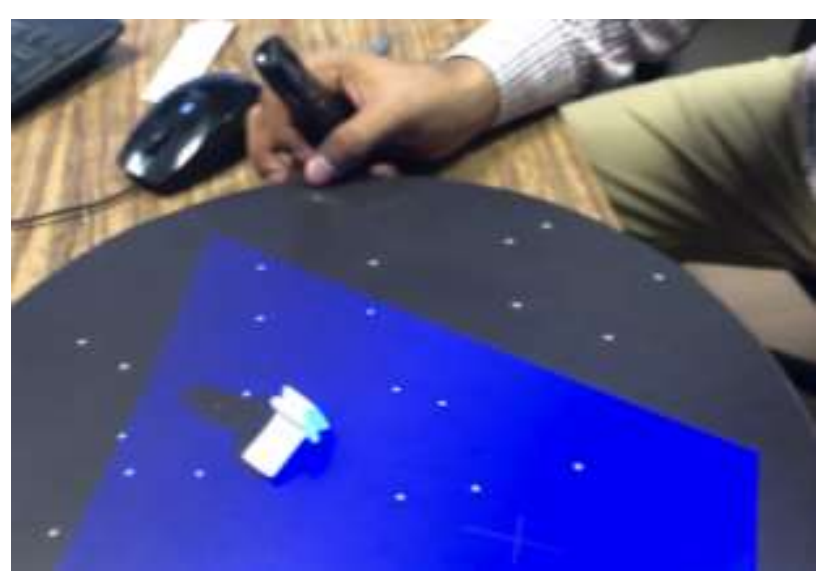

Figure 5 3D digitization process of blade. Note: Adapted "Study of wear damage in compressor turbine blades"(p. 76), Villagrán-Villegas L. , 2017

At the end of the process, a dot grid of axial compressor blade was obtained, one mesh with 93508 nodes (points). The model was optimized with GOM software and the model was reduced to 19938 nodes, which helps to optimized processing time. 

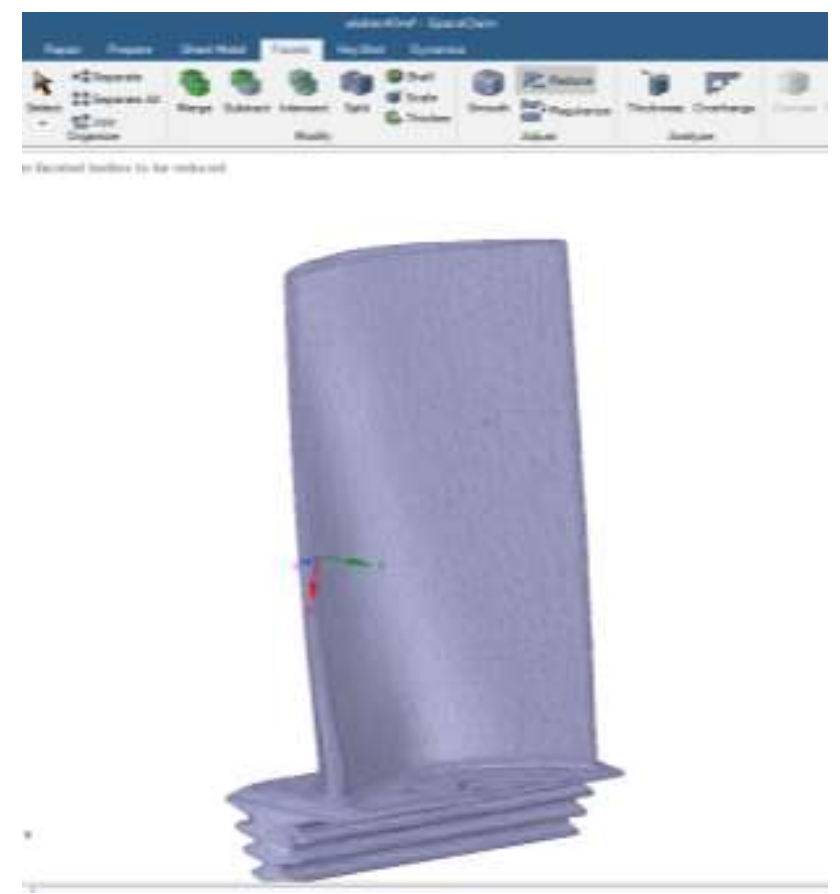

Figure 6 Model optimized with GOM software

\section{Conclusions}

After having carried out the dynamic simulation of the stresses to which the compressor blade is subjected, it was possible to verify the coincidence between the calculation developed with the evidence of the faults and wear found in the electronic scan carried out on the blade. A mesh points of axial compressor's blade was obtained, which allowed us to design a structural stress model.

With both analysis for the study of damage caused by wear in axial compressor's blades on a gas turbine will allow to characterize because the points, where pick stresses were calculated, correspond to those places in which corrosion and some irregular scratches similar to plowing action, was observed. These are the points in which failures take place. Therefore, there is now both theoretical and physical evidence of the areas where it will be necessary to inspect the compressor blades in the Solar Centaur 40 gas turbine installed in the marine weather conditions.

\section{References}

[1] Tabakoff, H. S. (1998). Blade Deterioration in a Gas Turbine Engine. (G. science, Ed.) International Journal of Rotating Machinery, 4 (4), p. 233-241.
[2] Pettit, F. S., \& Goward, G. W. (1981). High temperature corrosion and use of coatings for protection. Metallurgical Treatises, 1, p. 603619.

[3] Hutchings, I. (2003). Tribology (Vol. 1). (B. Heinemann, Ed.) London, London, UK: Elsevier Science.

[4] Kurz. (2014). Gas turbine degradation. Turbomachinery Laboratory, 1 (1), p. 36.

[5] NageswaraRao, M. (2011). Materials for Gas Turbines - An Overview, Advances in Gas Turbine Technology.Intech Europe, University Campus STePRi. Rijeka: Intech.

[6] Shilke, P. W. (2004). Advanced Gas Turbine Materials and Coatings. (Ge, Ed.) Ge Power, 1 (p. 356).

[7] R. Mendriky, Determination of measurement of accuracy of optical 3D scanner. Journal (Vol.1.) (2016), p.1565-1572.

[8] Mann BS. (1999) Solid-particle erosion and protective layers for steam turbine blading. Wear; 224: p. 8-12. 